\title{
Isabelle Thireau and Hua Linshan (eds), D'une illégitimité à l'autre dans la Chine rurale contemporaine
}

\section{Lucien Bianco}

\section{(2) OpenEdition Journals}

Electronic version

URL: http://journals.openedition.org/chinaperspectives/4293

DOI: 10.4000/chinaperspectives.4293

ISSN: 1996-4617

\section{Publisher}

Centre d'étude français sur la Chine contemporaine

\section{Printed version}

Date of publication: 1 July 2008

Number of pages: 155-157

ISSN: 2070-3449

\section{Electronic reference}

Lucien Bianco, «Isabelle Thireau and Hua Linshan (eds), D'une illégitimité à l'autre dans la Chine rurale contemporaine », China Perspectives [Online], 2008/3 | 2008, Online since 01 July 2008, connection on 24 September 2020. URL : http://journals.openedition.org/chinaperspectives/4293 ; DOI : https:// doi.org/10.4000/chinaperspectives.4293

This text was automatically generated on 24 September 2020 .

(c) All rights reserved 


\title{
Isabelle Thireau and Hua Linshan (eds), D'une illégitimité à l'autre dans la Chine rurale contemporaine
}

\author{
Lucien Bianco
}

1 Starting from 2000, the issue that most outraged farmers and stirred them to revolt was taxation in all its forms and with all its abuses, as eloquently illustrated in the wellknown survey carried out by Chen Guidi and Chun Tao in Anhui Province. ${ }^{1}$ More recently, "appropriations," "expropriations," or "requisitions" of land, although already being carried out in the 1990s, have increased to such an extent that they have replaced taxation as the principal grievance of farmers, at least in China's more developed east and south-east regions.

The precise causes, means, and consequences of this new phenomenon are clearly highlighted by this collection of articles, originally a special edition of the journal Etudes rurales. Starting with the introduction, the editors emphasise the scale of the phenomenon: in a country with less than one tenth of a hectare of arable land per capita, nearly six million hectares (or even more, according to one contributor, p. 120) have in recent years been lost to meet the needs of urbanisation, industry, and trade, or simply by being sold to the highest bidder by local authorities. Subject to bouts of "enclosure fever," officials have laid out "development zones" with a total surface area now exceeding that of urban areas. In 2006 alone, there were 131,000 recorded cases of illegal requisitioning of cultivated fields. It is now estimated that 50 million farmers have been deprived of land that had been assigned to them by contract at the beginning of the reforms, or reassigned at various times subsequently.

3 Two of the articles in the collection analyse in detail the means used in these appropriations (the word is more accurate than expropriations, since the farmers hold the lands they cultivate only in usufruct) and the profits made from them by the local authorities: one by He Bochuan, whose overly general title ("The agrarian crisis in China") is misleading, despite the introductory pages 117- 119, and one by Zhou Feizhou, "How local governments grow rich." The motivation of expropriating cadres 
having been revealed and the devastating effects eloquently exposed, the next two contributions recount (Ying Xing) and analyse (Kevin O'Brien and Li Lianjiang) farmers' resistance to these waves of land requisition and other abuses. Following a method often used in this book, Ying Xing presents the results of his research in a short general introduction that highlights its range. After referring to Duara, Fei Xiaotong, and the Imperial administration, the introduction quickly gets to the heart of the subject: the well-known "petitioning" system of letters and visits (xinfang) to the higher authorities, through which complaints and recriminations have been steadily increasing. The survey shows that the letters are virtually useless, and that the visits, while preferably collective, have to be repeated dozens of times in order to be heard. The administration plays for time in hopes of discouraging the plaintiffs, who ultimately often have no recourse but to provoke disorder (naoshi), and thus to infringe the law, the trick being to "bite the yellow line without crossing it." At this point the thread is taken up by O'Brien and Li's contribution ("Tactical escalation in rural China"), extracted from an excellent book for which I have already expressed my admiration elsewhere. ${ }^{2}$

While the originality (and the topicality) of this collective work owes much to its treatment of the "expropriations" and the new forms of farmer resistance, it also sheds light, especially in the first half, on past episodes that left their mark and reveal the methods of "mobilisation of the masses" tested early on by the regime. These are specifically those that marked the Maoist epic in the countryside: agrarian reform, the unified system of buying and selling (or food supply) (tonggou tongxiao) introduced in November 1953, the beginning of collectivisation, the Great Leap Forward, and the monumental works in Dazhai.

5 This retrospective on the years 1949-1976 occasionally gives the impression that some of the book's Chinese contributors have only recently discovered the other side of the glorious portrayal of the Revolution inculcated by propaganda. Far from being a criticism, this simply exemplifies the difference between the external observer, himself often long the victim of his illusions, and the subject treated as an object by the regime. As soon as they have seen the other side of the picture, the Chinese refine and document an analysis of the mechanisms of oppression much more effectively than non- Chinese do. In terms of documentation, a single example will suffice: I have long been familiar with the existence of theft, "the only way to survive"( p.89) during The Great Leap Forward, without being aware of its ubiquity, richly illustrated by Liu Xiaojing. On the mechanisms and effects of repression, the Western reader is likely to remember two things above all: the role played by violence and terror, and the perversion of language and human nature by the imposed recourse to normative arguments in which nobody believes.

6 From the beginning of agrarian reform, well analysed by Gao Wangling and Liu Yang, terror and "morality" are bound together and work towards the ideological transformation of the masses, who had hitherto considered it normal to pay rent for land. That terror killed many more than the campaign against counter-revolutionaries. Its targets included not only landlords (or farmers designated as such where landlords did not exist), but even people whose only fault was to be respected and influential in their village. The discrimination established - which is to say imposed and endured at that time has never been forgotten, according to Isabelle Thireau and Chang Shu, who analyse the tonggou tongxiao and the beginning of agrarian collectivisation. They 
describe the methods and deconstruct the process that ultimately imposes the required behaviour on farmers: exclusive value judgments and sham discussion, with the outcome determined beforehand. "Inside, I disagreed, but we could not be against it... We couldn't say nothing, nor could we say anything other than what they expected," an old farmer testifies (p.49). The contribution by Chang Shu and Hua Linshan shows that in Dazhai also, the range of permissible behaviour was extremely narrow (p. 107), and the prevailing Jesuitism incited people to confess even what they had not done but had only been tempted to do, such as not going to work when they were really too tired. And they were tired, exhausted, and prematurely worn out by colossal and unending exertion (up to 5,000 hours per year, three times the norm in France today) imposed, once again, by terror. Besides state aid, revealed only later, the great secret of the Dazhai miracle was terror.

7 After all these horrors, Wang Hansheng and Shen Jing's contribution is much more refreshing than might be suggested by its title ("The formation of property rights in the Chinese countryside"). It is also an effective antidote to the tendency toward clichés ("honest and naive farmers," etc.): it is a joy to discover the quibbles of villagers squabbling over the ownership of clinkers from which iron can be extracted and sold. The last article in the collection (by Jude Howell) also counters widespread illusions: an unexpected consequence of village elections is decreased female representation on village committees.

There are a few regrets, however: the author of the article on the record production rates during the Great Leap Forward tends to be overly critical (p. 63 and 76) of earlier studies (some of which, beginning with Thomas Bernstein's, published nearly a quarter of a century ago, ${ }^{3}$ are more illuminating than his own). Minor blunders and mistakes persist, possibly due to translation: the later Qing (p. 70), the Beifa dated to 1920 (p. 73); spelling is sometimes approximate. Finally, there is a lack of perspective on current conflicts: nowadays they focus more on the requisitioning of land than on taxes or the one-child policy simply because it is the scourge of the moment that gives rise to farmers' protests, being as they are, essentially reactive.

\section{NOTES}

1. Chen Guidi and Chun Tao, Zhongguo nongmin diaocha, Beijing, Renmin wenxue chubanshe, 2004.

2. Kevin J. O'Brien and Lianjiang Li, Rightful Resistance in Rural China, Cambridge University Press, 2006. Cf. my review in China Quarterly, No. 189, March 2007.

3. Thomas Bernstein, "Stalinism, famine, and Chinese peasants: Grain procurements during the Great Leap Forward," Theory and Society, 13-3, 1984, p. 339-377. 